\title{
Meningkatkan Hasil Belajar Siswa tentang Perkalian dan Pembagian Bilangan Cacah melalui Alat Peraga
}

\author{
Sri Suwarsih \\ SD Negeri Cipedak 06 Pagi Kecamatan Jagakarsa Jakarta Selatan \\ Jl. RM. Kahfi I Gg Swadaya, Cipedak, Kec. Jagakarsa, Jakarta Selatan, D.K.I. Jakarta, Indonesia \\ srisuwarsih1508@gmail.com
}

Artikel diterima: 5 Agustus 2018, direvisi: 21 September 2018, diterbitkan: 30 September 2018

\begin{abstract}
Abstrak
Berdasarkan pengalaman peneliti siswa kelas II, lemah dalam perkalian dan pembagian agar siswa kelas SD Negeri Cipedak 06 Pagi Kecamatan Jagakarsa Jakarta Selatan tidak mengalami kelemahan serupa maka perubahan pendekatan pembelajaran dengan menggunakan alat peraga. Hasil belajar digunakan guru untuk dijadikan ukuran atau criteria dalam mencapai suatu tujuan pembelajaran. Hal ini dapat tercapai apabila siswa sudah memahami belajar dengan diiringi oleh perubahan tingkah laku yang lebih baik lagi. Akan tetapi, hasil belajar matematika siswa pada umumnya belum menunjukkan hasil yang sesuai dengan yang diharapkan. Untuk itu, perlu ada kreativitas dari guru untuk menciptakan pembelajaran yang menyenangkan dan mudah dimengerti oleh siswa. Salah satunya pembelajaran dengan menggunakan alat peraga. Alat peraga merupakan salah satu media yang dapat digunakan untuk menyalurkan pesan dan dapat merangsang pikiran, perasaan, perhatian dan kemampuan siswa sehingga dapat mendorong terjadinya proses belajar pada diri siswa. Penelitian ini menggunakan metode Penelitian Tindakan Kelas yang pembelajaranya mengunakan alat peraga. Subyek dari penelitian ini adalah siswa kelas II SD Negeri Cipedak 06 Pagi Kecamatan Jagakarsa Jakarta Selatan. Jumlah siswa 29 orang. Instrumen yang digunakan dalam penelitian ini adalah instrument pengumpulan data. Berdasarkan dari jurnal harian siswa, sebagin besar siswa memberikan respon yang positif terhadap pembelajaran dengan mengunakan alat peraga.

Kata Kunci: hasil belajar, bilangan cacah, alat peraga.
\end{abstract}

Abstract (Enhancing Students' Learning Outcomes on Multiplication and Division of Natural Numbers through Teaching Aids)

Based on the experience of the researchers of class II students, weak in multiplication and division so that the students of Cipedak 06 Pagi Public Elementary School in Jagakarsa District, South Jakarta did not experience similar weaknesses, so the approach to learning by using props changed. Learning outcomes are used by teachers to be used as a measure or criterion in achieving an educational goal. This can be achieved if students have understood learning accompanied by better behavioral changes. However, students' mathematics learning outcomes in general have not shown results that are as expected. For that, there needs to be creativity from the teacher to create learning that is fun and easily understood by students. One of them is learning using teaching aids. Props are all things that can be used to channel messages and can stimulate students' thoughts, feelings, attention and abilities so as to encourage the learning process in students. This study uses a Classroom Action Research method that learners use teaching aids. The subjects of this study were second grade students of Cipedak 06 Pagi Elementary School, Jagakarsa District, South Jakarta. Number of students 29 people. The instrument used in this study is a data collection instrument. Based on students' daily journals, most students give a positive response to learning using teaching aids.

Keywords: learning outcomes, enumeration numbers, teaching aids. 


\section{Pendahuluan}

Pembelajaran matematika SD merupakan satu kajian yang selalu menarik untuk dikemukakan. Dengan latar belakang dan pola pikir anak yang berbeda pada setiap siswa. Adapun pola pikir pada siswa SD di kelas rendah (Kelas I, II, dan III) bukan tidak mungkin sebagian dari mereka masih berada pada tahapan pra konkret. Misalnya untuk memahami apa itu bola, mereka tidak bisa membayangkan seperti apa bola itu hanya melalui kata-kata. Guru harus membawa bola yang sebenarnya, dengan begitu siswa tahu bentuk bola seperti apa. Oleh karena itu alat peraga dalam pembelajaran Matematika di kelas rendah sangat di butuhkan, agar siswa lebih memahami materi yang dipelajari (Afiah, 2010:3)

Jika memperhatikan prestasi belajar siswa dalam pelajaran matematika, masih banyak siswa yang nilainya relatif rendah dengan melihat rata-rata kelas pada semester pertama 42,5. Namun, banyak siswa yang nilainya tinggi. Pembelajaran dikatakan berhasil jika ada timbal balik antara guru dan siswa, sehingga tujuan pembelajaran dapat tercapai, yang ditunjukan pada nilai evaluasi yang meningkat sesuai dengan Kriteria Ketuntasan Minimal (KKM).

Berdasarkan evaluasi kegiatan belajar mengajar di kelas II SD Negeri Cipedak 06 Pagi Kecamatan Jagakarsa Jakarta Selatan, menunjukan bahwa hasil ulangan Umum Semester I pada pelajaran Matematika kurang memuaskan, sekitar $65 \%$ dari jumlah 20 siswa mendapat nilai di bawah KKM. Maka dilaksanakan perbaikan pembelajaran melalui Penelitian Tindakan Kelas (PTK).

Permasalahan-permasalahan lain yang ditemukan di SD Negeri Cipedak 06 Pagi Kecamatan Jagakarsa Jakarta Selatan adalah: 1) Penggunaan alat peraga belum optimal karena kurangnya alat peraga yang tersedia di sekolah dan guru kurang kreatif dalam menciptakan alat peraga yang dibutuhkan; 2) Dalam proses belajar mengajar guru belum terbiasa menggunakan alat peraga; 3) Siswa belum menguasai pembelajaran matematika dengan menggunakan alat peraga tentang perkalian dan pembagian, sehingga hasil belajar siswa kurang memuaskan; dan 4) Hasil ujian semester tahun yang lalu mata pelajaran matematika lebih rendah dibandingkan dengan mata pelajaran lain.

Solusi yang dapat dilakukan untuk permasalahan di atas adalah: 1) Perlu adanya penambahan alat peraga di sekolah dan guru dituntut untuk lebih kreatif dalam menciptakan alat peraga yang dibutuhkan; 2) Sebaiknya guru harus terbiasa dalam menggunakan alat peraga; dan 3) Guru mampu menjelaskan tentang perkalian dan pembagian dengan menggunakan alat peraga agar siswa lebih memahami.

Pada penelitiannya, Nugraha dan Sundayana (2014) melihat dari perspektif siswa dan mengemukakan bahwa pembelajaran dengan dibantu alat peraga lebih menyenangkan dan mudah dipahami. Sedangkan, Tarusu (2018) 
melihat dari perspektif seorang guru dan mengungkapkan bahwa kemampuan dalam merancang dan melaksanakan pembelajaran sudah baik, namun dalam penggunaan media atau alat peraga pembelajaran yang masih kurang.

Pada pembelajaran matematika penggunaan alat peraga lebih ditingkatkan supaya hasil mata pelajaran matematika lebih tinggi dibandingkan dengan mata pelajaran yang lainnya. Guru matematika dapat mengaitkan setiap materi dengan aktivitas siswa dalam kehidupan seharihari dan kemudian secara perlahan mencari notasi formal/bentuk matematiknya (Afriansyah, 2012).

Matematika merupakan ilmu yang sangat penting dalam kehidupan manusia. Matematika digunakan di seluruh dunia sebagai alat penting di berbagai bidang, termasuk ilmu alam, teknik, kedokteran/medis, dan ilmu sosial seperti ekonomi, dan psikologi. Carl Friedrich Gauss) mengatakan matematika sebagai "Ratunya Ilmu Pengetahuan". Di dalam bahasa aslinya, Latin Regina scientiarum, juga di dalam bahasa jerman konigin der wissenschaften, kata yang bersesuaian dengan ilmu pengetahuan berarti (lapangan) pengetahuan. Jelas inipun arti asli di dalam bahasa inggris, dan tiada keraguan bahwa matematika di dalam konteks ini adalah sebuah ilmu pengetahuan.

Hasil belajar merupakan hal yang dapat dipandang dari dua sisi yaitu sisi siswa dan sisi guru. Dari sisi siswa, hasil belajar merupakan tingkat perkembangan mental yang lebih baik bila dibandingkan pada saat sebelum belajar. Tingkat perkembangan mental tersebut terwujud pada jenis jenis kognitif, afektif, dan psikomotor. Sedangkan dari sisi guru, hasil belajar merupakan saat terselesaikan bahan pelajaran. Dimyati dan Mudjiono (2006) mengatakan bahwa "Hasil belajar adalah bila seseorang telah belajar akan terjadi perubahan tingkat laku pada orang tersebut, misalnya dari tidak tahu menjadi tahu, dan dari tidak mengerti menjadi mengerti. Berdasarkan teori Taksonomi Bloom, hasil belajar dalam rangka studi dicapai melalui tiga kategori ranah yakni kognitif, afektif, psikomotor Tipe hasil belajar kognitif lebih dominan dari pada efektif dan psikomotor karena lebih menonjol, namun dari hasil belajar psikomotor dan efektif juga harus menjadi bagian dari hasil penilaian dalam proses pembelajaran di sekolah (Hamalik, 2011).

Beberapa penelitian telah meneliti tentang hasil belajar, dikaitkan dengan: Model Pembelajaran Generatif (Madio, 2012); Kooperatif Tipe Think Pair Share (Sari \& Madio, 2013); Motivasi Belajar (Warti, 2016); Model Active Knowledge Sharing (Sari, 2016); Model Pembelajaran Berbasis Masalah (Nst \& Rahmi, 2017); Strategi Pembelajaran Make a Match dan Index Card Match (Anggraini, Jufri, \& Juliati, 2017); Media Pembelajaran Komik (Florayu, Isnaini, \& Testiana, 2017); Problem Based Learning (Julita, 2018); Pengaruh Sikap Ilmiah (Razak \& Kamaruddin, 2018); dan Metode 
Pembelajaran STAD (Putri \& Sutriyono, 2018).

Untuk mengetahui pembelajaran seperti apa, terlebih dahulu kita lihat beberapa pengertian pembelajaran. Pembelajaran adalah proses interaksi peserta didik dengan pendidik dan sumber belajar pada satu lingkungan belajar. Pembelajaran merupakan bantuan yang diberikan pendidik agar dapat terjadi proses pemerolehan ilmu dan pengetahuan, penguasaan kemahiran dan tabiat, serta pembentukan sikap dan kepercayaan pada peserta didik. Dengan kata lain, pembelajaran adalah proses untuk membantu peserta didik agar dapat belajar dengan baik.

Media atau alat bantu mengajar adalah merupakan segala sesuatu yang dapat digunakan untuk menyalurkan pesan dan dapat merangsang pikiran, perasaan, perhatian dan kemauan siswa sehingga dapat mendorong terjadinya proses belajar pada diri siswa.

Adapun fungsi utama dari alat peraga adalah untuk menurunkan keabstrakan dari konsep, agar siswa mampu menangkap arti sebenarnya konsep tersebut.Dengan melihat, meraba, dan memanipulasi obyek/alat peraga, maka siswa mempunyai pengalamanpengalaman dalam kehidupan sehari-hari tentang arti dari suatu konsep.

\section{Metode}

Lokasi penelitian ini dilaksanakan di kelas II SD Negeri Cipedak 06 Pagi
Kecamatan Jagakarsa Jakarta Selatan, yang berlokasi di Kecamatan Jagakarsa Jakarta Selatan.

Subyek dalam penelitian adalah siswa kelas II SD Negeri Cipedak 06 Pagi Kecamatan Jagakarsa Jakarta Selatan. Denganjumlahsiswa 33 orang yang terdiridari 18 orang siswalaki-lakidan 16 orang siswaperempuan

Pelaksanaan penelitian ini dilakukan pada bulan April 2017 semester genap tahun ajaran 2016/2017. Penelitian ini dilaksanakan sebanyak 2 siklus 4 pertemuan. Adapun pelaksanaan penelitian, dimulai dengan tahap persiapan dilanjutkan dengan pelaksanaan tindakan dan diakhiri dengan penyusunan laporan hasil penelitian. Adapun jadwal pelaksanaan penelitian dapat dilihat pada tabel berikut:

Tabel 1.

Jadwal Pelaksanaan Penelitian

\begin{tabular}{|clc|}
\hline No. & \multicolumn{1}{c}{ Kegiatan } & \multicolumn{1}{c}{$\begin{array}{c}\text { Tanggal } \\
\text { Pelaksanaan }\end{array}$} \\
\hline 1 & Persiapan penelitian & 16 s.d 31 Mar \\
\hline 2 & Pelaksanaan Siklus I & 8 April 2017 \\
\cline { 3 - 3 } & 15 April 2017 \\
\hline 3 & Pelaksanaan Siklus II & 22 April 2017 \\
\cline { 3 - 3 } & 29 April 2017 \\
\hline 4 & $\begin{array}{l}\text { Pengolahan dan } \\
\text { Penggandaan Hasil } \\
\text { Penelitian }\end{array}$ & $\begin{array}{c}\text { 1 s.d 22 Mei } \\
\text { 2017 }\end{array}$ \\
\hline 5 & $\begin{array}{l}\text { Seminar Hasil } \\
\text { Penelitian }\end{array}$ & 30 Mei 2017 \\
\hline 6 & $\begin{array}{l}\text { Pelaporan Hasil } \\
\text { Penelitian }\end{array}$ & 5 Juni 2017 \\
\hline
\end{tabular}

Langkah-langkah PTK yang ditempuh dalam perbaikan pembelajaran matematika ini antara lain: 


\section{A. Perencanaan}

1. Peneliti melakukan analisis standar isi pada kurikulum pembelajaran untuk mengetahui kompetensi dasar yang akan disampaikan kepada siswa di kelas dengan menggunakan alat peraga dalam upaya meningkatkan hasil belajar siswa di kelas II.

2. Membuat rencana pembelajaran yang akan diberikan kepada siswa.

3. Membuat alat peraga yang sesuai dengan materi yang akan disampaikan.

4. Menyiapkan dan membuat lembar kerja siswa.

5. Menyusun alat evaluasi pembelajaran.

B. Tindakan

1. Menginformasikan tujuan pembelajaran yang akan dicapai serta menyampaikan informasi tentang langkah-langkah pembelajaran yang akan dilakukan.

2. Menyajikan materi dengan menggunakan alat peraga yang sesuai.

3. Melakukan evaluasi pembelajaran.

4. Menutup pembelajaran dengan memberi penguatan materi.

C. Observasi

1. Penggunaan alat peraga sesuai dengan materi pembelajaran.

2. Mengamati respon siswa terhadap pembelajaran dengan menggunakan alat peraga.

3. Mengamati keaktifan siswa dalam pembelajaran.

4. Pemberian evaluasi dan penguatan materi.

D. Refleksi

1. Harapan guru agar siswa lebih memperhatikan penjelasan guru.

Mosharafa: Jumal Pendidikan Matematika

Volume 7, Nomor 3, September 2018

Copyright @ 2018 Mosharafa: Jurnal Pendidikan Matematika
2. Kegiatan belajar mengajar berlangsung sesuai dengan yang diharapkan oleh guru.

3. Siswa menyelesaikan evaluasi sesuai dengan petunjuk dari guru.

Instrumen pengumpulan data yang digunakan dalam penelitian ini adalah:

1. Instrumen Tes

Instrumen Tes yang digunakan adalah tes uraian. Tujuan menggunakan tesuraian adalah untuk mengetahui proses berpikir matematika siswa dalam mengerjakan evaluasi secara individu, serta untuk mengetahui sejauh mana hasil belajar siswa meningkat jika menggunakan alat peraga.

E. Teknik Pengumpulan Data/Analisis Data

1. Data aktivitas siswa dikumpulkan dengan menggunakan lembar observasi.

2. Data nilai hasil tes siswa diperoleh setelah proses pembelajaran, yaitu di akhir pembelajaran.

3. Pencatatan dilakukan oleh guru yang berhubungan dengan aktifitas siswa selama proses pembelajaran berlangsung.

4. Semua hasil observasi, pencatatan dan hasil tes siswa pada siklus pertama dibandingkan dengan siklus kedua.

5. Data yang terkumpul sebagian besar adalah kuantitatif.

Indikator penelitian tindakan kelas ini dapat dilihat dari beberapa kegiatan yang dilakukan selama berlangsungnya proses pembelajaran. 
1. Keaktifan siswa dalam pembelajaran matematika mengalami peningkatan sebesar $80 \%$.

2. $95 \%$ siswa Kelas IISD Negeri Cipedak 06 Pagi Kecamatan Jagakarsa Jakarta Selatan mengalami ketuntasan belajar individual, nilai lebih dari 65 dalam pembelajaran matematika.

3. Target minimal yang ingi dicapai oleh peneliti yang sesuai dengan standar di Sekolah tentang Kriteria Ketuntasan Minimal adalah 65.

Tabel 2. Kriteria Ketuntasan Minimal

\begin{tabular}{ccc}
\hline No & Nilai & Kriteria \\
\hline 1 & $<65$ & $\begin{array}{c}\text { Tidak Tuntas } \\
\text { (Remidi) }\end{array}$ \\
\hline 2 & $65-90$ & Tuntas \\
\hline 3 & $91-100$ & Pengayaan \\
\hline
\end{tabular}

\section{Hasil dan Pembahasan}

\section{A. Aktivitas Siswa Selama Proses Pembelajaran dengan Menggunakan Alat Peraga}

Dalam pembelajaran dengan menggunakan alat peraga lebih banyak melibatkan siswa dalam kegiatan pembelajaran, karena siswa diajak untuk menggunakan alat peraga dan menumbuhkan keberanian dalam diri siswa.

Pada siklus I, hampir semua siswa belum memahami materi yang dipelajari, hal itu disebabkan mereka tidak terbiasa belajar dengan menggunakan alat peraga, akan tetapi siswa cukup senang dalam melakukan pembelajaran dengan menggunakan alat peraga walaupun ada beberapa orang siswa yang mengeluh karena tidak diberi kesempatan untuk menggunakan alat peraga.

Kekurangan pada siklus I ini akan diperbaiki pada kegiatan siklus II Pada siklus II, semakin banyak siswa yang antusias dalam pembelajaran menggunakan alat peraga. Tetapi ada beberapa siswa mengeluh bosan.

Karena alat peraga yang digunakan selalu sama walaupun ada yang ditambahkan. Dikelas guru bukan hanya sebagai pendidik ataupun pengajar, tapi juga sebagai fasilitator yang membantu siswa dalam mencapai tujuan pembelajaran. Guru pun harus mampu menciptakan suasana pembelajaran yang menyenangkan dan bermakna.

Dalam mengerjakan soal evaluasi pada setiap pertemuan, siswa sangat antusias karena soal telah disediakan oleh guru dan mereka tidak perlu menulis soal kembali. Untuk melihat gambaran hasil observasi aktivitas guru dan siswa selama siklus pembelajaran, berikut disajikan grafik perbandingannya: 


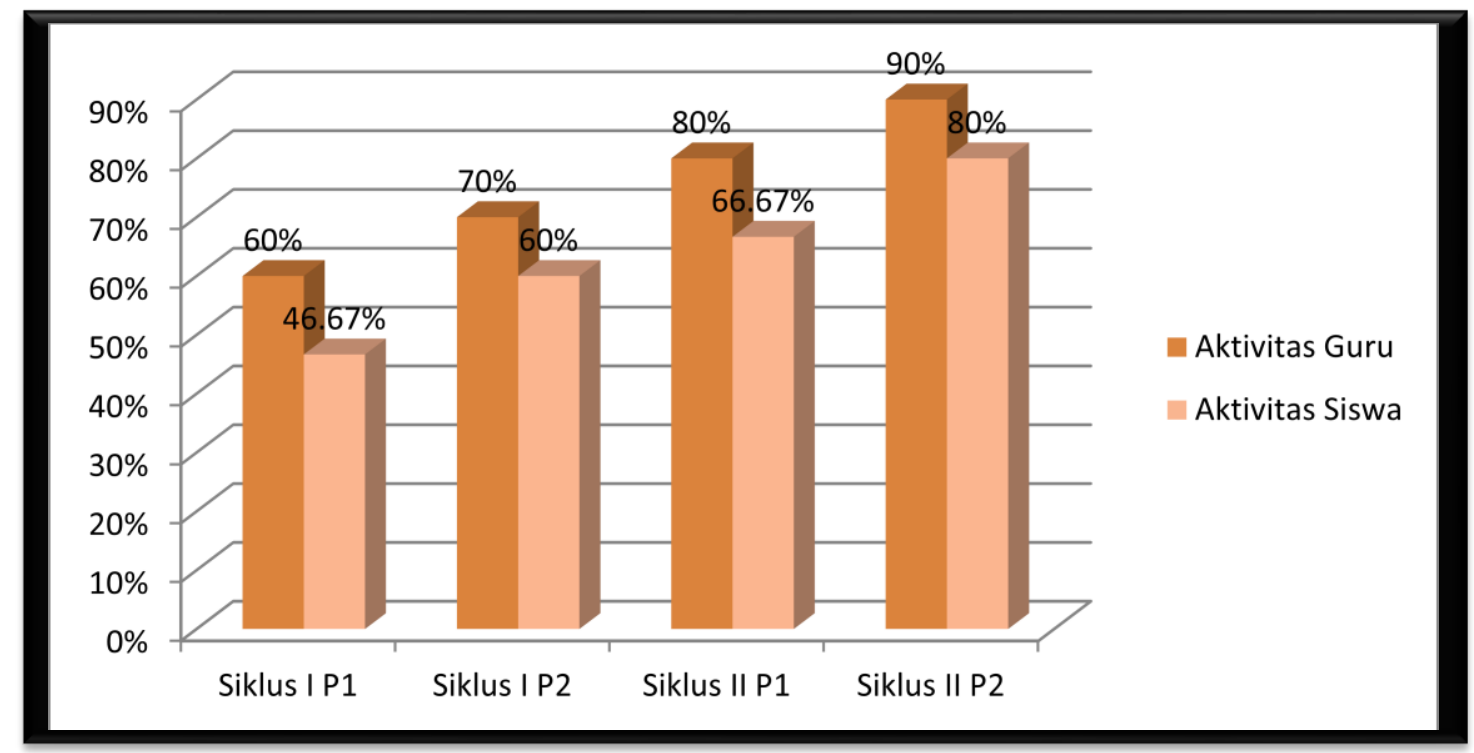

Gambar 1. Hasil Observasi Guru dan Siswa Tiap Siklus.

Berdasarkan grafik di atas dapat dilihat terdapat peningkatan kualitas aktivitas pembelajaran oleh guru dan siswa pada setiap siklus nya.

\section{B. Hasil Tes Evaluasi Siswa selama Proses Pembalajaran Setelah Menggunakan Alat Peraga}

Soal evaluasi dibuat adalah untuk mengetahui peningkatan hasil belajar siswa dalam mata pelajaran matematika setelah guru mennggunakan alat peraga. Berikut grafik peningkatan kemampuan siswa dari siklus I sampai siklus II.

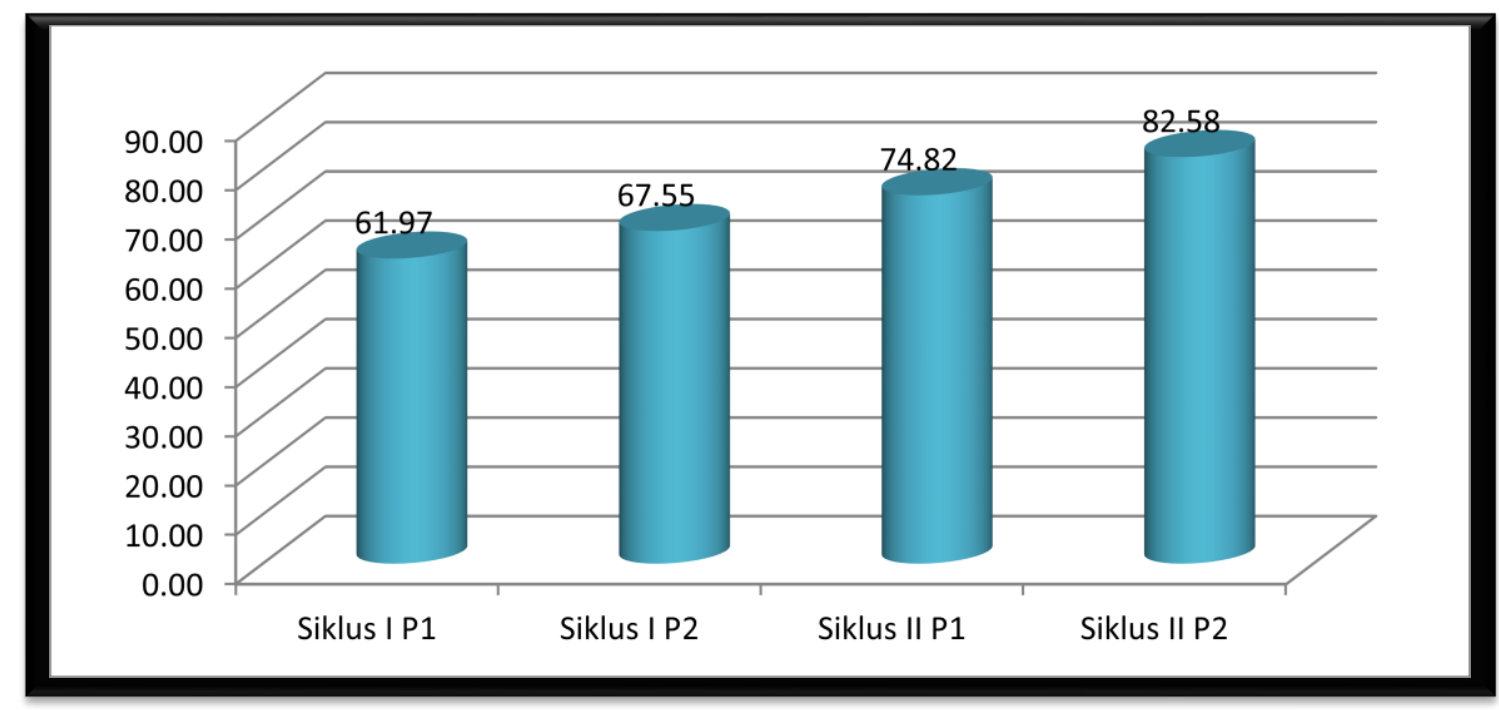

Gambar 2. Peningkatan Kemampuan Siswa dari Siklus I sampai II.

\section{Mosharafa: Jurnal Pendidikan Matematika}


Berdasarkan grafik diatas dapat dilihat, rata-rata keseluruhan nilai yang diperoleh oleh siswa selama dua siklus mengalami peningkatan di setiap siklusnya, diman siklus I pertemuan 1 rata-rata nilai yang diperoleh mencapai 61,97, meningkat di siklus I pertemuan 2 menjadi 67,55, siklus
II pertemuan 2 74,82, dan di siklus II pertemuan 2 menjadi 82,58. Ini menunjukan bahwa penggunaan alat peraga dalam pembelajaran pemahaman perkalian dan pembagian dalam bilangan cacah berpengaruh signifikan terhadap peningkatan hasil belajar siswa.

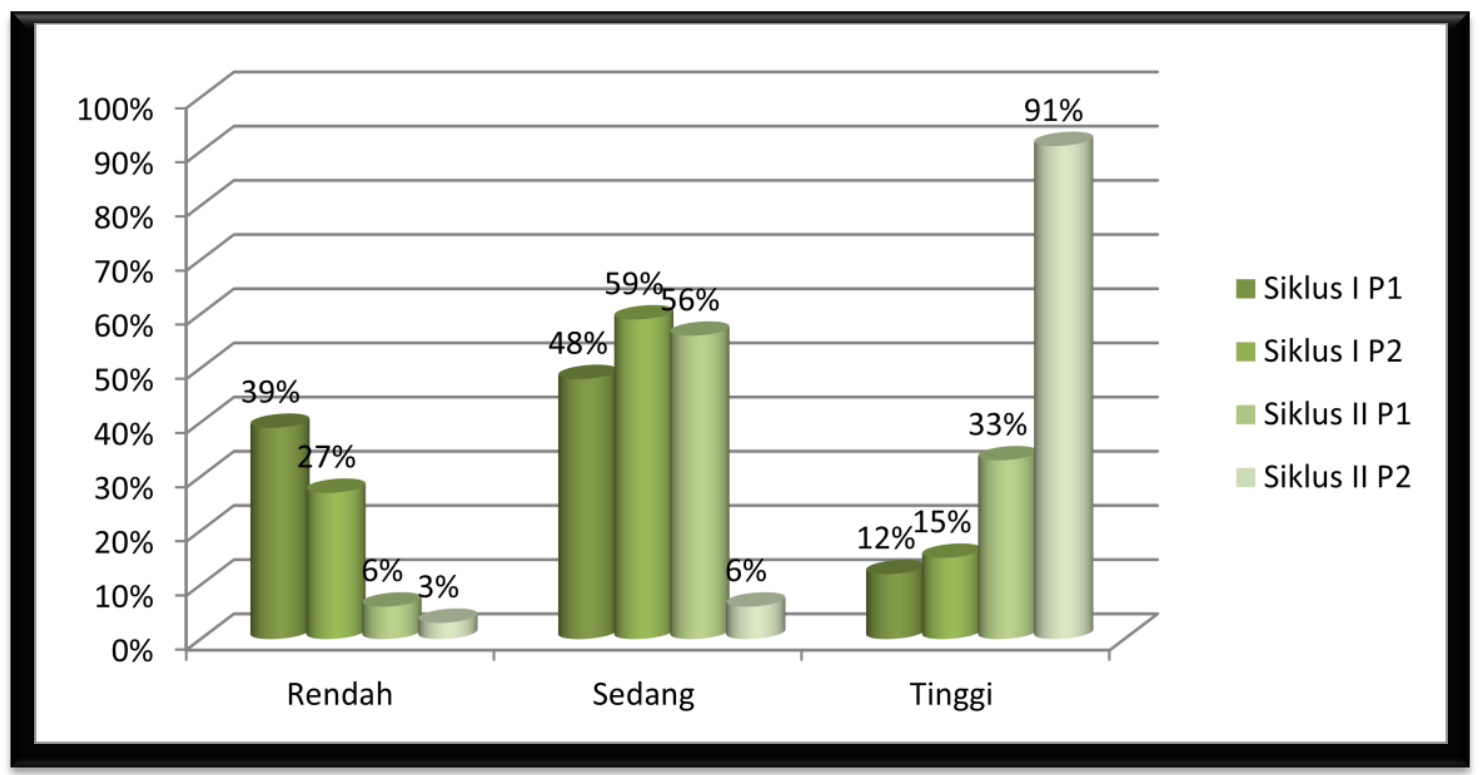

Gambar 3. Peningkatan Hasil Belajar Tiap Siklus.

Dari grafik di atas dapat disimpulkan bahwa pada setiap pertemuan pada siklus I sampai dengan siklus II, menunjukkan adanya peningkatan yang cukup signifikan terhadap peningkatan hasil belajar siswa yang diukur dari setiap siklus.

Berdasarkan pemaparan kegiatan belajar mengajar diatas, peneliti dalam melakukan penelitian menemui beberapa kendala diantaranya:

1. Kesulitan dalam menyusun administrasi pembelajaran seperti RPP dan alat evaluasi, karena peneliti melakukan penelitian terhadap siswa kelas II dimana pembelejarannya menggunakan tematik, sehingga sedikit kesulitan dalam menyusun administrasi pembelajaran tersebut terutama menyusun alat evaluasi.

2. Sulitnya mengatur waktu dalam pembelajaran, karena semua siswa ingin menggunakan alat peraga sedangkan waktu yang tersedia tidak cukup.

3. Sulit untuk membuat siswa memahami apa yang disampaikan guru dengan alat

Mosharafa: Jumal Pendidikan Matematika Volume 7, Nomor 3, September 2018 Copyright $\odot 2018$ Mosharafa: Jurnal Pendidikan Matematika 
peraga, karena siswa lebih terpaku pada alat peraga saja tanpa memperhatikan materi yang dimaksudkan dalam penggunaan alat peraga.

C. Respon Siswa Terhadap Pembelajaran Matematika Dengan Menggunakan Alat Peraga Berdasarkan Jurnal Harian Yang Diisi Siswa Setiap Pertemuan

Jurnal harian merupakan media bagi siswa untuk mengemukakan kesan dan pendapat mereka terhadap pembelajaran matematika. Jurnal harian ini diisi oleh siswa pada setiap akhir pembelajaran disetiap pertemuan. Jurnal harian ini terdiri dari tiga pertanyaan yaitu tentang apa yang dipelajari hari ini, perasaan siswa pada pembelajaran ini, dan apa saja yang kurang pada pembelajaran hari ini.

Dalam jurnal harian, respon siswa dikelompokkan kedalam respon positif dan respon negatif, kemudian data tersebut dihitung persentasenya. Berikut ini adalah diagram respon siswa pada setiap siklus.

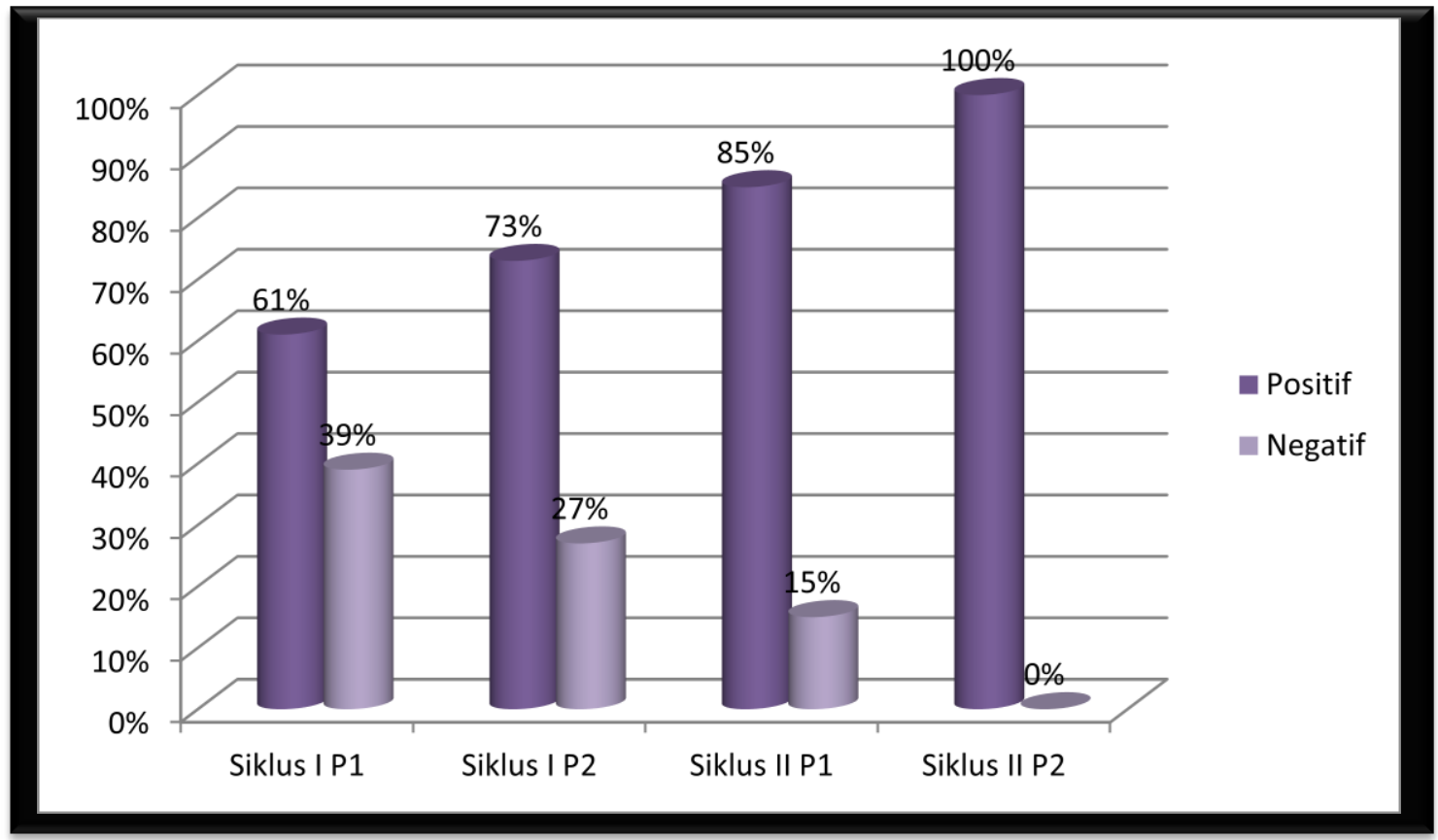

Gambar 4. Respon SIsiwa Tiap Siklus.

Pada umumnya siswa sangat menyukai pembelajaran matematika dengan menggunakan alat peraga, karena mereka bisa terlibat langsung dalam pembelajaran dengan cara menggunakan alat peraga. Mereka bisa belajar sambil bermain.

\section{Penutup}

Berdasarkan pembahasan, maka dapat diambil kesimpulan sebagai berikut: 1) Penggunaan alat peraga dalam pembelajaran matematika telah dilaksanakan dengan baik, walaupun masih ada kekurangan tetapi membuat 
pelajaran matematika lebih menyenangkan dan siswa pun lebih aktif dibandingkan dengan sebelum menggunakan alat peraga; 2) Respon siswa terhadap pembelajaran matematika dengan menggunakan alat peraga sangat baik. Siswa sangat antusias dalam belajar, siswa pun menjadi lebih berani bila ditunjuk ke depan oleh guru. Masih ada beberapa siswa yang merasa bosan, mungkin karena mereka tidak mendapatkan giliran untuk menggunakan alat peraga tersebut; dan 3) Pembelajaran matematika dengan menggunakan alat peraga dapat meningkatkan hasil belajar siswa, walaupun peningkatannya tidak terlalu signifikan. Meningkatnya hasil belajar siswa ini dipicu dari suasana pembelajaran yang menyenangkan, sehingga siswa lebih memahami materi yang disampaikan oleh guru.

\section{DAFTAR PUSTAKa}

Afiah, E. (2010). Meningkatkan pemahaman siswa Kelas III SD dalam matapelajaran Matematika Melalui Metode STAD. Syarat memperoleh gelar sarjana pada FKIP Universitas Pakuan Bogor: tidak diterbitkan.

Afriansyah, E. A. (2012). Implementasi PMRI dalam Materi Sifat Komutatif dan Asosiatif pada Bilangan Bulat untuk Level Siswa SD/MI. Mosharafa: Jurnal Pendidikan Matematika, 1(2), 67-72.

Anggraini, V., Jufri, L. H., dan Juliati, W. (2017). Peningkatan Hasil Belajar Matematika Siswa Menggunakan
Strategi Pembelajaran Make a Match dan Index Card Match pada Siswa Kelas VIII SMPN 1 Koto XI Tarusan Tahun Pelajaran 2016/2017. Mosharafa: Jurnal Pendidikan Matematika, 6(2), 201-206.

Dimyati dan Mudjiono. (2006). Belajar dan Pembelajaran. Jakarta: Rineka Cipta.

Florayu, B., Isnaini, M., dan Testiana, G. (2017). Pengaruh Penggunaan Media Pembelajaran Komik terhadap Peningkatan Hasil Belajar Matematika Siswa Kelas VII di Sekolah Menengah Pertama Negeri 10 Palembang. Mosharafa: Jurnal Pendidikan Matematika, 6(1), 45-51.

Hamalik, O. (2011). Kurikulum dan Pembelajaran. Jakarta: PT Bumi Aksara. Hal. 157-159.

Julita. (2018). Peningkatan Kemampuan Pemecahan dan Hasil Belajar Matematika melalui Problem BasedLearning. Mosharafa: Jurnal Pendidikan Matematika, 7(1), 143154.

Madio, S. S. (2012). Model Pembelajaran Generatif dalam Upaya Meningkatkan Hasil Belajar Matematika. Mosharafa: Jurnal Pendidikan Matematika, 1(1), 29-34.

Nst, M. N. dan Rahmi, R. (2017). Pengaruh Penerapan Model Pembelajaran Berbasis Masalah disertai Teknik Berikan Uangnya terhadap Hasil Belajar Matematika Siswa Kelas VIII SMPN 16 Padang. Mosharafa: Jurnal Pendidikan Matematika, 6(2), 273278.

Mosharafa: Jurnal Pendidikan Matematika Volume 7, Nomor 3, September 2018 Copyright @ 2018 Mosharafa: Jurnal Pendidikan Matematika 
Nugraha, A. dan Sundayana, R. (2014). Penggunaan Alat Peraga sebagai Upaya untuk Meningkatkan Prestasi Belajar dalam Memahami Konsep Bentuk Aljabar pada Siswa Kelas VIII di SMPN 2 Pasirwangi. Mosharafa: Jurnal Pendidikan Matematika, 3(3), 133142.

Putri, K. C. dan Sutriyono. Pengaruh Metode Pembelajaran STAD terhadap Hasil Belajar Matematika pada Siswa Kelas VIII. Mosharafa: Jurnal Pendidikan Matematika, 7(2), 295306.

Razak, F. dan Kamaruddin, R. (2018). Pengaruh Sikap IImiah Siswa terhadap Hasil Belajar Materi Bangun Ruang Siswa Kelas VIII SMP Negeri 3 Minasatene. Mosharafa: Jurnal Pendidikan Matematika, 7(1), 133142.

Sari, E. F. P. (2016). Penerapan Model Active Knowledge Sharing dalam Pembelajaran Matematika Siswa Kelas VII di SMPN 18 Palembang. Mosharafa: Jurnal Pendidikan Matematika, 5(3), 335-342.

Sari, S. P. dan Madio, S. S. (2013). Pengaruh Penerapan Model Pembelajaran Kooperatif Tipe Think Pair Share (TPS) terhadap Hasil Belajar Matematika Siswa SMP. Mosharafa: Jurnal Pendidikan Matematika, 2(1), 37-54.

Tarusu, D. T. (2018). Kemampuan Pedagogik Matematika SD pada Mahasiswa PGSD FIP UNIMA.
Mosharafa: Jurnal Pendidikan Matematika, 7(2), 263-272.

Warti, E. (2016). Pengaruh Motivasi Belajar Siswa terhadap Hasil Belajar Matematika Siswa di SD Angkasa 10 Halim Perdana Kusuma Jakarta Timur. Mosharafa: Jurnal Pendidikan Matematika, 5(2), 177-185. 
This page is intentionally left blank 